\title{
SEJARAH SOSIAL KABUPATEN LEBAK
}

\section{SOCIAL HISTORY OF KABUPATEN LEBAK}

\author{
Oleh Adeng \\ Balai Pelestarian Nilai Budaya Bandung \\ Jalan Cinambo No.136 Ujungberung Bandung \\ Email: adeng.tedja@ymail.com
}

Naskah Disetujui: 1 April 2013

\begin{abstract}
Abstrak
Tulisan mengenai Sejarah Sosial Daerah Kabupaten Lebak menggambarkan kehidupan masyarakat yang mencakup aspek geografi, pemerintahan, penduduk, budaya sinkretisme dan masyarakat adat, budaya, dan pendidikan. Untuk merekontruksi kembali menggunakan metode sejarah yang meliputi empat tahap, yaitu: heuristik, kritik, interpretasi, dan historiogarfi. Lebak menjadi bagian dari wilayah Kesultanan Banten dan masyarakatnya menganut ajaran agama Islam. Pada abad ke-19 terjadilah perubahan politik di daerah tersebut. Perubahan itu seiring dengan semakin meluasnya kekuasaan Belanda di wilayah Banten yang ditandai oleh penghapusan Banten tahun 1808 oleh Daendels. Perkembangan selanjutnya pada masa pemerintahan Letnan Gubernur Jenderal Thomas Stamford Raffles (1811-1816), Banten dibagi menjadi empat daerah setingkat kabupaten, yaitu: Kabupaten Banten Lor, Banten Kulon, Banten Tengah, dan Banten Kidul. Setelah kekuasaan dipegang kembali oleh Belanda, maka wilayah Banten dibagi menjadi 3 kabupaten yaitu: Kabupaten Serang, Caringin, dan Lebak. Perubahan berikutnya terjadi pada tanggal 14 Agustus 1925, Lebak menjadi sebuah kabupaten otonom. Kemudian, pada tahun 1950 mengenai pembentukan daerah-daerah dalam lingkungan Provinsi Jawa Barat. Kabupaten Lebak dimasukkan ke dalam 25 Daerah Tingkat II di provinsi tersebut. Pada tahun 2003 Kabupaten Lebak menjadi bagian dari Provinsi Banten. Penduduk Kabupaten Lebak dari tahun ke tahun mengalami perkembangan yang signifikan, begitu pula di bidang sosial budaya dan pendidikan berkembang cukup dinamis.
\end{abstract}

Kata kunci: Lebak, sosial, budaya, pemerintahan.

\begin{abstract}
This study illustrates aspects of community life in Kabupaten Lebak in the $19^{\text {th }}$ century. Then, Lebak was part of the Sultanate of Banten and most of the people embraced Islam. In the $19^{\text {th }}$ century Lebak faced a political change due to the expanding power of the
\end{abstract}


Dutch in Banten. Daendels eliminated the Sultanate of Banten in 1808. During the reign of Lieutenant Governor-General Thomas Stamford Raffles (1811-1816) Banten was divided into four districts: Banten Lor (Northern Banten), Banten Kulon (Western Banten), Banten Tengah (Central Banten), and Banten Kidul (Southern Banten). When the Dutch regained its power in Banten, the region was divided into three disctricts: Serang, Caringin, and Lebak. In August 14, 1925 Lebak became an autonomous district. In 1950 District of Lebak was part of 25 districts in the Province of West Java, and since 2005 the district became part of the Province of Banten. Today, the population of Lebak has been increasing significantly every year and the educational and socio-cultural life has been developed quite dynamically. To reconstruct this history the author conducted method in history: heuristic, criticism, interpretation, and historiography.

Keywords: Lebak, social, culture, government

\section{A. PENDAHULUAN}

Penelitian dan penulisan Sejarah Sosial Daerah di Indonesia dapat dikatakan masih jarang. Tulisan-tulisan sejarah pada umumnya didominasi oleh sejarah politik yang isinya lebih banyak menguraikan sistem pemerintahan raja-raja, zaman Kolonial Belanda, zaman Pendudukan Jepang, dan zaman revolusi. Khusus di daerah Jawa Barat (termasuk Banten sebelum menjadi provinsi), kegiatan dalam bidang sejarah baru berada pada taraf inventarisasi dan dokumentasi. Itu pun uraiannya lebih menitikberatkan pada inventarisasi data-data sejarah politik, yakni Sejarah Revolusi Kemerdekaan, Sejarah Perlawanan terhadap Imperalisme dan Kolonialisme Jawa Barat, Sejarah Pemerintahan Jawa Barat, Sejarah Tatar Sunda, dan lain-lain. Sedangkan di tingkat kabupaten rata-rata baru disusun sejarah hari jadi kabupaten, itu pun hasilnya masih banyak kekuranganya. Banyak hari jadi di tingkat kabupaten masih dipermasalahkan atau masih ada yang pro dan kontra tentang penanggalannya. Hal ini disebabkan kurangnya sumber-sumber primer untuk merekontruksi kembali sejarah masa lampau atau menyusun sejarah yang utuh.

Selain itu, tulisan-tulisan sejarah yang paling banyak dilakukan adalah bercorak sejarah militer yang isinya menguraikan pertempuran-pertempuran, terutama pada periode revolusi fisik (1945-1949). Mengesankan bahwa sejarah itu milik kaum politikus dan militer. Padahal sejarah adalah mencatat/menulis segala aktivitas dan kejadian yang berhubungan dengan manusia di muka bumi ini 
Penulisan ini bertujuan untuk mendeskripsikan secara historis-sosiologis tentang peristiwa`sosial budaya, sehingga dapat diketahui bagaimana dinamika kehidupan masyarakat Lebak pada waktu itu. Hasil penulisan sejarah sosial ini dapat dijadikan sebagai rekomendasi dan pengembangan serta pembangunan masyarakat Lebak di masa yang akan datang.

Penulisan ini selain memperhatikan sejarah sosial itu sendiri, juga meninjau perkembangan fisik kota seperti geografi, penduduk, pemerintahan, budaya, dan pendidikan. Untuk merekonstruksi itu digunakan metode sejarah yang meliputi empat tahap, yaitu: heuristik, kritik, interprestasi, dan historiogarfi. Pada tahap heuristik dilakukan pengumpulan sumber, baik sumber primer maupun sumber sekunder. Terhadap sumber yang telah diperoleh dilakukan kritik ekstern dan kritik intern, untuk menentukan otentisitas sumber dan kredibilats data/informasi. Selanjutnya, pada tahap interpretasi, data mengalami proses pemberian makna dan penafsiran sehingga fakta-fakta tersebut dapat menjelaskan objek studi secara jelas dan lengkap. Proses terakhir adalah historiografi yang bertujuan untuk merangkaikan fakta-fakta yang berhasil dihimpun dalam sebuah jalinan kisah sejarah yang objektif.

\section{B. HASIL DAN BAHASAN}

\section{Keadaan Geografi}

Secara geografis Kabupaten Lebak terletak pada posisi $106^{0} 00^{\prime}-106^{02} 21$ ' Bujur Timur dan $5^{0}-10^{0} 00^{\prime}$ Lintang Selatan (Suyitno et al., 1991: 276). Pegunungan Kendeng menjadi pembelah antara Lebak bagian Utara dan Selatan. Dengan adanya Gunung Kendeng ini maka kontur tanah di Kabupaten Lebak datar bergelombang dengan variasi ketinggian antara 0--1000 meter di atas permukaan laut (dpl). Perinciannya adalah ketinggian 0--200 m di atas permukaan laut berada di kawasan pantai, 201--500 m di atas permukaan laut di Lebak bagian tengah, 501--1000 m di atas permukaan laut di Lebak bagian timur. Kabupaten Lebak memiliki luas wilayah sekitar 304.472 ha $\left(3.044,72 \mathrm{~km}^{2}\right)$, dengan batas wilayah administratif sebagai berikut: sebelah utara Kabupaten Serang dan Tangerang, sebelah selatan Samudera Indonesia, sebelah barat Kabupaten Pandeglang, dan sebelah timur Kabupaten Bogor dan Kabupaten Sukabumi (Adeng et al., 2011: 9-10) 
Curah hujan rata-rata tiap tahun antara 2000 - 4000 mm. Posisi Gunung Kendeng yang membelah Lebak menjadikan sebelah selatan lebih banyak menerima curah hujan daripada bagian utaranya, hal ini disebabkan daerah Selatan yang berhadapan langsung dengan Samudera Hindia relatif lebih cepat membentuk awan hujan akibat uap air lautnya, sedangkan bagian utara terhalang oleh puncak Gunung Kendeng. Suhu rata-rata $24^{0}-25^{\circ} \mathrm{C}$ (Sucipto et al., 2000: 11-12).

Gunung Kendeng selain menjadi pembatas alam juga merupakan sumber mata air bagi aliran sungai-sungainya. Ci Ujung adalah sungai terbesar yang mengalir dari selatan ke utara kemudian menyebarkan aliran airnya melalui dua anak sungai yaitu Ci Simeut dan Ci Laki. Anak Ci Ujung yang mengalir ke arah barat adalah Ci Liman. Aliran air sungai ini akhirnya bermuara di Teluk Lada. Sungai lain yang mengalir ke arah selatan relatif lebih kecil yaitu Ci Langkahan, Ci Pager, Ci Mandiri, Ci Pandalan, dan Ci Sawarna. Sungaisungai ini bermata air di Pegunungan Kendeng dan bermuara di Samudera Indonesia.

Sebagai kabupaten yang menitikberatkan pembangunan daerahnya di bidang pertanian, kondisi dan jenis tanah di Kabupaten Lebak termasuk potensial. Tercatat lima jenis tanah yaitu: podsolik merah kuning, latosol, aluvial, regosol, dan tanah hutan coklat non kalsit (Ensiklopedia Nasional 1990: 334).

Kondisi tanah ini juga menjadi potensi bagi hasil tambang yang terkandung di dalamnya. Kabupaten Lebak memiliki bahan tambang emas, perak, minyak bumi, dan biji besi yang sudah dikelola baik secara tradisional maupun dengan teknologi modern. Batubatu mulia dan jenis batu yang potensil untuk dijadikan komoditas bagi pendapatan asli daerah (PAD) juga dapat ditemui di kabupaten ini. Batu-batu tersebut dari jenis batu gamping, batu bara, andesit, deolit, bentonit, pasir kuarsa, kalsit, gips, marmer, batu hias, batu apung, dan batu karang. Batu mulia dari Kabupaten Lebak yang terkenal sampai ke mancanegara adalah Batu Kali Maya yang dapat dijumpai di dalam tanah dan sungai yang mengalir di Kecamatan Maja (Adeng et al., 2011: 11-12).

\section{Pemerintahan}

Kabupaten Lebak, dalam tradisi setempat disebut Jagat Kidul atau Banten Kidul (Banten Selatan) bagian dari wilayah Kesultanan Banten. Pada abad ke-19 terjadilah perubahan politik di daerah tersebut. Perubahan itu seiring dengan semakin meluasnya 
kekuasaan Belanda di wilayah Banten yang ditandai oleh penghapusan Banten tahun 1808 oleh Daendels. Wilayah bekas kekuasaan Kesultanan Banten dibagi dua menjadi Caringin dan Serang (Lubis et al., 2006: 148-149).

Berubahnya status Banten dari sebuah kesultanan menjadi wilayah yang terdiri dari kabupaten-kabupaten terjadi pada masa pemerintahan Letnan Gubernur Jenderal Thomas Stamford Raffles (1811-1816). Pada tanggal 19 Maret 1813, Raffles memaksa Sultan Banten, Muhammad Syarifuddin membuat surat perjanjian yang isinya menyatakan penyerahan pemerintah Banten kepada pemerintah Inggris. Status sultan kemudian diubah menjadi bupati dengan sebutan bupati sultan. Kemudian Reffles melakukan reorganisasi atas wilayah Banten pada tahun yang sama. Banten dibagi menjadi empat daerah setingkat kabupaten, yaitu: Kabupaten Banten Lor (Banten Utara), Kabupaten Banten Kulon (Banten Barat), Kabupaten Banten Tengah, dan Kabupaten Banten Kidul (Banten Selatan) (Lubis et al., 2006: 149-150).

Kekuasaan Inggris atas Hindia Belanda hanya berlangsung sekitar 5 tahun. Sesuai perjanjian yang dituangkan dalam Traktat London, 13 Agustus 1814, pihak Inggris harus menyerahkan kembali seluruh wilayah Hindia Belanda kepada pemerintah Belanda, termasuk Banten. Pada tanggal 19 Agustus 1816 dilakukan serah terima kekuasaan dari pemerintah Inggris kepada Belanda di Batavia (Lubis et al., 2006: 150-151).

Setelah kekuasaan dipegang kembali oleh pemerintah Belanda, maka wilayah Banten direorganisasi kembali. Sesuai dengan Surat Keputusan Komisaris Jenderal Nomor 1, Staatsblad Nomor 81, tanggal 2 Desember 1828, wilayah Keresidenan Banten dibagi menjadi 3 kabupaten yaitu: Kabupaten Serang, Kabupaten Caringin, dan Kabupaten Lebak. Wilayah Kabupaten Lebak berdasarkan pembagian di atas memiliki 4 distrik yaitu: Distrik Sajira meliputi Onderdistrik Ciangsa, Somang, dan Sajira; Distrik Lebak Parahiyang meliputi Onderdistrik Koncang dan Parahiyang; Distrik Parungkujang meliputi Onderdistrik Parungkujang dan Kosek; Distrik Madhoor (Madur) yang meliputi Onderdistrik Binuangeun, Sawarna, dan Madhoor (Sutisna et al., 2004: 10).

Adanya surat keputusan tentang pembagian wilayah Banten, maka pada tanggal 2 Desember 1828 dijadikan acuan dalam penentuan hari jadi Kabupaten Lebak. Hal ini telah dikukuhkan dalam Peraturan Daerah (Perda) No. 18 Tahun 1986 tertanggal 22 Oktober 1986 yang menetapkan hari jadi Kabupaten Lebak adalah tanggal 2 Desember 1828 (Sucipto et al., 2000: 17). 
Perkembangan berikutnya, ketika Hindia Belanda dipimpin oleh Gubernur Jenderal Frederik's Jacob (1881-1884), wilayah Kabupaten Lebak yang semula terdiri atas empat distrik mengalami pemekaran. Pemekaran itu tertuang dalam Staatblad No. 266, tanggal 29 Oktober 1882. Wilayah Kabupaten Lebak dibagi atas lima distrik, yaitu: Distrik Rangkasbitung yang meliputi wilayah Rangkasbitung, Kolelet Wetan, Warunggunung, dan Cikulur; Distrik Lebak yang meliputi wilayah Lebak, Muncang, Cilaki, dan Cikeuyeup; Distrik Sajira yang meliputi wilayah sajira, saijah, Candi, dan Maja; Distrik Parungkujang yang meliputi wilayah Parungkujang, Kumpay, Cileles, dan Bojongmanik; Distrik Cilangkahan yang meliputi wilayah Cipalabuh, Cihara, dan Bayah (Sucipto et al., 2000: 18)

Perubahan berikutnya terjadi pada tanggal 14 Agustus 1925 yaitu dengan diberlakukannya Staatsblad No. 381 tahun 1925, Lebak menjadi sebuah kabupaten otonom yang memiliki 5 distrik yaitu Distrik Parungkujang, Rangkasbitung, Lebak Parahiyang, dan Cilangkahan. Sajira yang tadinya adalah sebuah distrik masuk menjadi bagian dari Distrik Lebak Parahiyang. Kemudian, berdasarkan Undang-undang Nomor 14 Tahun 1950 mengenai pembentuk daerah-daerah dalam lingkungan Provinsi Jawa Barat. Kabupaten Lebak dimasukkan ke dalam 25 Daerah Tingkat II di provinsi tersebut (Sucipto et al., 2000: 18).

Perkembangan selanjutnya, pada tahun 1986, Kabupaten Lebak terdiri atas 4 pembantu kabupaten, 15 kecamatan, 13 kematren (perwakilan kecamatan), 5 kelurahan, dan 295 desa. Pada masa itu Kabupaten Lebak masih menjadi bagian dari Provinsi Jawa Barat. Tahun 2003 Kabupaten Lebak semakin berkembang dengan bertambahnya jumlah wilayah kecamatan akibat adanya program pemekaran wilayah. Jumlah kecamatan menjadi 23 buah, 5 kelurahan, dan 295 desa. Pada masa ini Kabupaten Lebak kembali menjadi bagian dari Provinsi Banten yang dibentuk berdasarkan Undang-undang Nomor 23/2000 tanggal 17 Oktober 2000, tentang Pembentukan Provinsi Banten (Adeng et al., 2011: 9).

\section{Penduduk}

Jumlah penduduk Kabupaten Lebak ketika dibawah kekuasaan Gubernur Jenderal van den Bosch (1830-1834) mengalami penurunan yang drastis karena pada waktu itu telah diberlakukannya sistem tanam paksa. Adanya tanam paksa, rakyat menjadi tidak sempat mengurusi lahan pertaniannya untuk mencukupi kebutuhan hidup sehari-harinya. Akibatnya banyak rakyat yang jatuh sakit dan mati kelaparan karena kurangnya sandang dan pangan. 
Selain itu, banyak terjadi kasus kriminalitas atau perampokan-perampokan sehingga tidak sedikit dari rakyat yang menjadi korban pembunuhan.

Jumlah penduduk Kabupaten Lebak dari tahun 1834-1840 yaitu, sebagai berikut:

TABEL 1

JUMLAH PENDUDUK KABUPATEN LEBAK 1834-1840

\begin{tabular}{|l|l|l|l|l|l|}
\hline \multirow{2}{*}{ Tahun } & \multicolumn{4}{|c|}{ Distrik } & \multirow{2}{*}{ Sumlah } \\
\cline { 2 - 6 } & $\begin{array}{c}\text { Lebak } \\
\text { Parahiyang }\end{array}$ & Cilangkahan & Sajira & Parungkujang & \\
\hline 1834 & 19.847 & 15.306 & 12.256 & 20.160 & 67.569 \\
\hline 1835 & 19.188 & 10.762 & 12.897 & 18.896 & 61.743 \\
\hline 1836 & 18469 & 12.056 & 13.573 & 17.726 & 61.824 \\
\hline 1837 & 18.272 & 9.877 & 13.385 & 14.667 & 56.201 \\
\hline 1838 & 17.331 & 8.084 & 12.619 & 14.760 & 52.794 \\
\hline 1840 & 17.145 & 6.356 & 13.836 & 15.754 & 53.090 \\
\hline
\end{tabular}

Sumber: Lubis et al., 2006: 176-181.

Perkembangan selanjutnya, jumlah penduduk Kabupaten Lebak dari tahun 18501877 mengalami peningkatan yang cukup berarti yaitu, sebagai berikut:

TABEL 2

JUMLAH PENDUDUK KABUPATEN LEBAK 1850-1877 


\begin{tabular}{|l|r|l|r|l|l|l|}
\hline \multirow{2}{*}{ Tahun } & \multicolumn{5}{|c|}{ Distrik } & \\
\cline { 2 - 7 } & Lebak & Cilangkahan & Sajira & $\begin{array}{l}\text { Parung- } \\
\text { kujang }\end{array}$ & $\begin{array}{l}\text { Warung- } \\
\text { gunung }\end{array}$ & \\
\hline 1850 & 10.110 & 13.048 & 12.456 & 10.896 & 16.198 & 62.708 \\
\hline 1852 & 8.175 & 12.140 & 9.858 & 11.806 & 23.636 & 65.615 \\
\hline 1860 & 12.876 & 11.397 & 14.772 & 12.698 & 27.772 & 79.640 \\
\hline 1864 & 12.608 & 11.121 & 15.762 & 13.703 & 28.558 & 81.879 \\
\hline 1876 & 20.526 & 22.823 & 23.649 & 21.300 & 34.261 & 122.559 \\
\hline 1877 & 20.701 & 23.199 & 24.091 & 23.050 & 36.166 & 127.207 \\
\hline
\end{tabular}

Sumber: Lubis et al., 2006: 184.

Jumlah penduduk Kabupaten Lebak dari tahun ke tahun terus merangkak naik secara signifikan sesuai dengan perkembangan yang semakin kompleks. Pada tahun 1920 jumlah penduduk Kabupaten Lebak berdasarkan sensus penduduk adalah 206.672 orang dengan kepadatan 62 orang $/ \mathrm{km}^{2}$. Sepuluh tahun kemudian (1930) jumlah penduduk bertambah menjadi 256.158 orang dengan kepadatan 77 orang $/ \mathrm{km}^{2}$. Sekitar tiga puluh tahun kemudian (1961) jumlah penduduk makin meningkat menjadi 413.242 orang dengan kepadatan 90 orang $/ \mathrm{km}^{2}$ (Lubis et al., 2006: 287-290).

Dari tahun 1961 sampai tahun 1990 jumlah penduduk Kabupatern Lebak menjadi 873.670 orang dengan kepadatan 287 orang $/ \mathrm{km}^{2}$. Dari tahun 1990 hingga tahun 2004 jumlah penduduk mencapai 1.156 .436 orang dengan kepadatan 380 orang $/ \mathrm{km}^{2}$ (Lubis, et al., 2006: 290 - 291). Sedangkan dari tahun 2004 sampai dengan tahun 2008 jumlah penduduk mencapai 1.233.905 orang (Lebak Dalam Angka Tahun 2005).

\section{Budaya Sinkretisme dan Masyarakat Adat}

Sebelum agama Islam masuk ke wilayah Banten dan sekitarnya termasuk Lebak, penduduknya masih menganut agama Hindu dan Sunda Wiwitan. Hal ini dapat dipahami karena wilayah Banten dan sekitarnya termasuk Lebak, pada waktu itu di bawah kekuasaan Kerajaan Sunda yang menganut ajaran Hindu.

Setelah Sunan Gunung Jati menyebarkan ajaran agama Islam di Banten dan sekitarnya termasuk Lebak, penduduknya baru masuk agama Islam. Apalagi setelah Banten dan sekitarnya diambilalih oleh Sunan Gunung Jati dari tangan kekuasaan Kerajaan Sunda, ajaran agama Islam semakin berkembang (Adeng 2007: 6). 
Meskipun masyarakat Lebak sudah memeluk agama Islam, namun sebagian masyarakatnya masih menjalankan ajaran atau adat yang diwarisi dari leluhur mereka, baik seluruhnya maupun sebagian. Kemudian masyarakat tersebut dikenal sebagai entitas sosial yang mengembangkan sistem kapuunan dengan beberapa variannya. Sistem kapuunan atau telu tangtu hidup dan terus tumbuh dalam komunis masyarakat Baduy. Sementara itu, varian dari sistem kapuunan adalah sistem kaolotan atau kasepuhan yang hingga batas-batas tertentu terus berkembang di beberapa desa di Kecamatan Cibeber, Lebak Selatan (Lubis et al., 2006: 99-100).

Kehidupan orang Baduy terisolasi selama berabad-abad hingga sekarang, sikap hidup mereka selalu menolak masuknya kebudayaan luar dan mempertahankan tradisi leluhur mereka. Oleh karena itu, masyarakat Baduy masih banyak menyimpan unsur, pola, dan sistem masyarakat kebudayaan Sunda lama. Dengan kata lain, masyarakat Baduy masih lebih mencerminkan tipe masyarakat dan kebudayaan Sunda lama dibandingkan dengan kelompok masyarakat Sunda lainnya (Ekadjati, 1995: 60).

Tetapi mereka bukan masyarakat terasing, terpencil, atau pun masyarakat yang terisolasi dari perkembangan dunia luar. Pada saat tertentu, mereka menerima para tamu yang sengaja berkunjung ke wilayahnya, bahkan untuk menginap satu atau dua malam pun diperbolehkan, asal pengunjung mengikuti atau mentaati adat istiadat yang berlaku, antara lain tidak boleh menggunakan sabun dan odol saat mandi di sungai, berpoto di wilayah Baduy Dalam. Demikian pula, pada saat lain mereka berkelana ke suatu kota untuk mencari pengalaman (Lubis et al., 2006: 103).

Tradisi Baduy bersendikan kehidupan tapa di mandala. Tapa bukan berarti bersemedi tetapi selalu tekun bekerja, sedikit berbicara dan tidak menganggur. Bekerja itulah yang menjadi tapa. Bekerja bukan berarti mencari harta kekayaan yang berlebihan tetapi sekedar cukup menghidupi keluarga sendiri tidak menyusahkan orang lain. Sebagai penghuni mandala, kehidupan mereka harus lebih sederhana dibanding dengan kehidupan orang yang melakukan tapa di nagara. (Lubis et al., 2006: 115-117 dan Ekadjati, 1995: 69).

Di dalam pemerintahan, masyarakat Baduy mengenal dua sistem pemerintahan, yaitu: pertama, sistem pemerintahan tradisional atau sistem adat yang mengikuti aturan adat istiadat yang dipercaya oleh masyarakat Baduy. Kedua, sistem pemerintahan modern atau sistem pemerintahan yang berlaku sekarang, yaitu mengikuti aturan negara Indonesia. Kedua 
sistem tersebut digabung atau diakulturasikan sedemikian rupa sehingga tidak terjadi benturan. Secara nasional, penduduk Baduy dipimpin oleh seorang kepala desa (kades) yang disebut sebagai jaro pamarentah, yang ada di bawah camat, sedangkan secara adat tunduk pada pimpinan adat Baduy, yaitu Pu'un. Jabatan Pu'un berlangsung turun-temurun, namun di sini bukan berarti otomatis dari kakek turun ke bapak kemudian ke anak, melainkan dapat juga kerabat lainnya yang lebih mampu menduduki dan menjalankan adat istiadat. Jangka waktu jabatan Pu'un tidak ditentukan, hanya berdasarkan pada kemampuan seseorang memegang jabatan tersebut (Ekadjati, 1995: 69).

Dalam pelaksanaan sehari-hari, pemerintahan adat kapu'unan dilaksanakan oleh jaro, yang dibagi ke dalam empat jabatan, yaitu: jaro tangtu, jaro dangka, jaro tanggungan, dan jaro pamarentah. Jaro tangtu bertanggung jawab pada pelaksanaan hukum adat pada warga tangtu dan berbagai macam urusan lainnya. Jaro dangka bertugas menjaga, mengurus, dan memelihara tanah titipan leluhur yang ada di dalam dan di luar Kanekes. Jaro dangka berjumlah 9 orang, yang apabila ditambah dengan 3 orang jaro tangtu disebut sebagai jaro duabelas. Pimpinan dari jaro dua belas ini disebut sebagai jaro tanggungan. Adapun jaro pamarentah secara adat bertugas sebagai penghubung antara masyarakat adat Baduy dengan pemerintah nasional, yang dalam tugasnya dibantu oleh pangiwa, carik, dan kokolot lembur atau tetua kampung (Makmur, 2001).

Dalam mata pencaharian, semua orang Baduy hidup dari hasil bertani. Petanian yang digarapnya ialah sistem huma, yaitu menanam padi di hutan. Menggarap tanah dengan sistem sawah atau menanam padi di sawah merupakan tabu bagi mereka. Selain itu, mereka juga mendapatkan penghasilan tambahan dari usaha menyadap enau untuk dijadikan gula merah, mencari madu di hutan, berburu di hutan, mencari ikan di sungai, menjual buah-buahan yang mereka tanam seperti durian, asam keranji, rambutan, kelapa, pisang, dan petai.

Pada masyarakat Baduy, tanah bukanlah status hak milik secara pribadi. Tanah, termasuk hutan di sekitarnya, dianggap oleh mereka sebagai barang titipan kepada mereka dari yang lebih kuasa (raja,Yang Mahakuasa). Mereka bertugas untuk memeliharanya sebatas untuk memenuhi kebutuhan hidup mereka. Sehubungan dengan hal itu, lahan huma yang digarap oleh mereka, bukanlah lahan milik pribadi, melainkan lahan garapan pribadi. Jadi, hanya hasil garapannya menjadi milik pribadi, tetapi tanahnya tidak boleh menjadi hak milik pribadi (Ekadjati, 1995: 92-93). 


\section{Kehidupan Sosial Budaya}

Masyarakat Kabupaten Lebak mayoritas orang Sunda. Oleh karena itu, kehidupan sehari-harinya tidak jauh berbeda dengan orang Sunda lainnya yang ada di daerah Jawa Barat. Masyarakat Kabupaten Lebak sejak dulu mempunyai kehidupan sosial yang sangat tinggi. Keramahtamahan penduduknya adalah sebagai bukti dari nilai kehidupan sosial yang dapat dibanggakan. Kehidupan gotong royong dari masyarakat desa mencerminkan kepribadian sosial sejak nenek moyangnya seperti tercermin pada masyarakat Baduy yang telah diuraikan di atas.

Menurut Koentjaraningrat (1984: 6), gotong royong adalah salah satu unsur (aktivitas) dalam organisasi sosial yang merupakan suatu konsep atau nilai kebersamaan (kerja sama) dan merupakan sifat positif dalam mentalitas masyarakat. Gotong royong merupakan cerminan dari manusia yang merupakan makhluk hidup sosial tidak bisa hidup sendiri, karena dikelilingi oleh sistem sosial dan komunitas yang selalu terikat. Jika gotong royong dilihat sebagai kebudayaan, di dalamnya terdiri atas 3 wujud, yakni; gotong royong bisa dilihat sebagai sistem ide (nilai, norma, aturan), sistem sosial (aktivitas kerja sama atau tindakan), dan hasil tindakan/aktivitas dari gotong royong (terwujudnya jalan, perbaikan rumah) (Rostiyati, 2011: 2).

Kemudian menurut Heddy Shri Ahimsa Putra (2004: 47), gotong royong adalah salah satu unsur organisasi sosial yang merupakan aktivitas kerja sama. Organisasi sosial kerja sama (gotong royong) biasanya ditujukan untuk mengatasi masalah-masalah umum yang dihadapi para anggotanya, dan kegiatan tersebut biasanya hanya dapat diselenggarakan dengan bantuan banyak orang (Rostiyati, 2011: 2).

Kedua pendapat tersebut pada dasarnya sama, bahwa gotong royong merupakan kerja sama, baik untuk kepentingan umum maupun untuk membantu seseorang bila membutuhkan bantuan atau pertolongan, baik itu ketika ada musibah maupun ada maksud tertentu, seperti menikah, khitanan, dan sebagainya. Untuk kepentingan umum, gotong royong dilakukan misalnya untuk membersihkan gorong-gorong atau saluran air supaya bila musim hujan tiba air bisa mengalir dengan lancar dan tidak menimbulkan banjir. Kemudian membersihkan lingkungan setempat supaya tidak menimbulkan penyakit, seperti demam berdarah (DB), malaria, dan sebagainya. Hal ini tercermin di masyarakat Kabupaten Lebak baik di pedesaan maupun di lingkungan kompleks perumahan. 
Berdasarkan status sosial, masyarakat Lebak mengenal beberapa pelapisan sosial dalam kehidupan mereka. Pertama masyarakat yang mempunyai hubungan darah atau keturunan Kesultanan Banten. Kelompok masyarakat ini dipandang sebagai kaum bangsawan (kaum menak) yang mempunyai gelar tubagus bagi kaum pria dan ratu bagi kaum perempuan. Selain yang bergelar tubagus dan ratu, ada juga bangsawan yang bergelar raden. Berdasarkan keterangan dari tokoh masyarakat setempat, gelar kebangsawanan ini diturunkan dari kaum bangsawan yang berasal dari Priangan. Gelar kebangsawanan ini disandang secara turun temurun, namun ada juga yang diberikan oleh Pemerintah Hindia Belanda. Gelar kebangsawanan yang diberikan oleh Pemerintah Hindia Belanda biasanya bernama Sastrawiguna atau Sastranegara (Lubis et al., 2006: 211-212).

Kedua, kelompok masyarakat yang menempati golongan bangsawan rendah. Kelompok masyarakat ini menyandang gelar entol. Gelar kebangsawanan ini disandang oleh mereka yang mempunyai hubungan darah atau keturunan Ajar Djo. Menurut cerita masyarakat setempat, Ajar Djo merupakan salah seorang hulubalang pasukan perang Prabu Pucuk Umum. Bersama-sama dengan saudara kandungnya yang bernama Ajar Djong, mereka menyatakan diri menganut agama Islam dan menjadi pengikut setia Maulana Hasanuddin. Oleh karena pengabdiannya itu, maka oleh Sultan Hasanuddin mereka diberi gelar sehingga namanya berubah menjadi Ki Mas Djong dan Ki Mas Djo. Kelak di kemudian hari, keturunan dari Ki Mas Djo ini diberi gelar entol (Lubis et al., 2006: 213).

Pada abad ke-19 stratifikasi atau pelapisan sosial masyarakat Lebak terbagi tiga lapisan, yaitu golongan elit, golongan jawara, dan golongan pamong praja atau orang kaya. Golongan elit yaitu kaum ulama, status ini mendapat tempat yang tinggi pada masyarakat Lebak. Sebagai seorang ulama memiliki kemampuan yang memadai dalam bidang keagamaan. Tidaklah heran, jika dia menjadi tempat yang tepat untuk didatangi orang yang ingin mendapatkan siraman rohani. Golongan Jawara, pada zamannya dikenal memiliki keberanian, kemampuan, dan kekuatan fisik yang dapat membuat orang takut dan segan jika berhadapan dengan mereka. Golongan pamong praja, yaitu mereka merupakan aparat pemegang kekuasaan formal yang kadang-kadang lebih membela kepentingan penguasa daripada rakyatnya. Selain itu, mereka yang diakui oleh masyarakat sebagai orang kaya. Orang kaya ini biasanya memiliki harta kekayaan yang berlebih, seperti rumahnya banyak, sawah dan kebunnya luas (Sucipto et al., 2000: 45-47). 
Kebudayaan Lebak yang berkembang didominasi oleh kebudayaan Sunda. Begitu pula halnya dengan kesenian sebagai salah satu wujud kebudayaan juga didominasi oleh kesenian Sunda. Kesenian tradisional dan upacara tradisional peninggalan dari nenek moyang yang sampai sekarang masih eksis terutama di daerah Kanekes, seperti: Kesenian Angklung, dog dog Lojor, Debus, Rudat, Ubrug, Wayang Golek, dan sebagainya. Pada mulanya fungsi kesenian tradisional adalah sebagai bagian dari upacara yang berkaitan dengan keagamaan. Namun seiring dengan perkembangan zaman fungsinya telah berubah menjadi media hiburan.

Kesenian Angklung di daerah Kanekes digunakan untuk upacara menanam padi di huma dan untuk hiburan. Angklung untuk upacara dengan Angklung untuk hiburan berbeda dan begitu pula cara membunyikannya. Angklung untuk upacara dibunyikannya bebas atau dikurulungkeun itu berlaku untuk di Baduy Dalam. Sedangkan di Baduy Luar, angklung dibunyikannya dengan ritmis tertentu. Meski demikian, masih bisa ditampilkan di luar upacara tetapi mempunyai aturan, misalnya hanya boleh ditabuh hingga masa ngubaran pare, sekitar tiga bulan dari sejak ditanamnya padi. Setelah itu, selama enam bulan berikutnya tidak boleh dibunyikan atau dimainkan, dan boleh dimainkan lagi pada musim menanam padi berikutnya. Angklung tersebut disimpan di tempat penyimpanan yang telah disediakan (Adeng et al., 2011: 23-24).

Angklung untuk hiburan biasanya dimainkan saat terang bulan dan tidak hujan. Mereka memainkan angklung di halaman rumah sambil menyanyikan bermacam-macam lagu, antara lain: Yandu Bibi, Oray-orayan, Dengdang, Yari Gandang, Ayun-ayunan, Pileuleuyan, dan sebagainya. Para penabuh angklung sebanyak delapan orang, dan tiga penabuh bedug ukuran kecil membuat posisi berdiri sambil berjalan dalam formasi lingkaran. Sementara itu yang lainnya ada yang menari dengan gerakan tertentu yang telah baku tetapi sederhana. Semuanya dilakukan hanya oleh laki-laki orang Baduy Luar. Sedangkan orang Baduy Dalam, tidak boleh melakukannya karena dibatasi oleh adat atau pantangan/tabu, tidak boleh melakukan hal-hal yang sifatnya kesenangan duniawi yang berlebihan. Kesenian hanya semata-mata dilakukan untuk keperluan upacara atau ritual saja. Adapun nama-nama angklung di Kanekes, yaitu: indung, ringkung, dongdong, gunjing, engklok, indung leutik, torolok, dan roel. Roel yang terdiri dari 2 buah angklung dipegang oleh seorang. Waditra lainnya, yaitu: bedug, talingtit, dan ketuk (Adeng et al., 2011: 23-24). 
Kesenian Dogdog Lojor salah satunya terdapat di Kecamatan Bayah, Kabupaten Lebak. Dogog Lojor berasal dari dua kata dalam bahasa Sunda, dogdog dan lojor; dogdog adalah nama alat musik yang apabila dipukul menimbulkan bunyi $\operatorname{dog} \ldots$ dog...dog, dengan demikian alat itu dinamai "dogdog”, sedangkan kata lojor dalam bahasa Sunda Banten artinya panjang. Jadi nama dogdog Lojor adalah dogdog yang bentuknya panjang (Sariyun et al., 1991: 46)

Pada masa lampau, kesenian ini merupakan alat pelengkap upacara adat, misalnya upacara sesudah panen, ngalaksa, seren taun dan ngaruat, maksudnya untuk memohon keselamatan bagi kampung, keselamatan sesudah membuat rumah, dan menempati pemukiman atau tempat yang baru. Dengan perkembangan zaman, kesenian dogdog lojor bukan hanya dijadikan sebagai pelengkap upacara adat tetapi sekarang dijadikan sebagai alat hiburan seperti khitanan, pernikahan, dan sebagainya.

Kesenian Debus merupakan kesenian asli masyarakat Banten yang tersebar ke Kabupaten Serang, Lebak, dan Pandeglang. Debus berasal dari kata tembus. Dalam antraksinya digunakan benda tajam yang terbuat dari besi dan digunakan untuk melukai diri sendiri atau menguji kekebalan tubuh. Oleh karena itu kata debus dapat diartikan juga sebagai tidak tembus. Kesenian ini alkulturasi dari kebudayaan pra- Islam dengan nilai-nilai ke-Islaman, maksudnya supaya dalam rangka penyebaran agama Islam dapat diterima dengan mudah oleh masyarakat kala itu. Jadi di dalam kesenian Debus dimasukkan unsur-unsur dzikir dan salawat Nabi dengan maksud mengolah bathin dan menambah rasa keimanan kepada Alloh SWT.

Ada beberapa versi yang menguraikan mengenai asal-usul kesenian Debus di daerah Banten. Versi pertama menyebutkan bahwa sejarah kesenian Debus di Banten bermula pada abad ke-16 pada masa pemerintahan Sultan Maulana Hasanuddin (1532-1570). Ketika itu seni debus merupakan salah satu media penyebaran agama Islam. Versi kedua menyebutkan bahwa seni debus sudah ada semenjak abad 13 yang berasal dari daerah Al-Madad di Timur Tengah. Kesenian ini disebarkan ke daerah Banten pada waktu itu sebagai media penyebaran agama Islam. Versi ketiga menyebutkan bahwa kesenian debus berasal dari daerah Aceh yang bersumber dari ajaran Tarekat Rifa'iyah Nuruddin Ar-Raniry. Tarekat Rifa'iyah mengajarkan rasa gembira saat bertemu Allah Swt atau disebut epiphany. Saat seseorang 
telah mencapai puncak epiphany dia akan kebal terhadap benda tajam apa pun (Adeng et al., 2011: 46-47).

Benang merah dari ketiga versi tersebut adalah kesenian Debus sebagai metode penyebaran agama Islam di wilayan Banten pada masa itu. Pada masa Sultan Ageng Tirtayasa (1651-1692 M), debus menjadi media untuk memompa semangat juang rakyat Banten melawan penjajah Belanda (Sariyun et. al., 1991: 30). Dewasa ini kesenian Debus dijadikan sebagai pertunjukan atau alat hiburan. Karena kesenian Debus sudah dikombinasi antara seni tari, suara serta seni kebatinan dengan nuansa magis.

Kesenian Rudat, di Kabupaten Lebak dikenal juga dengan istilah kesenian Kitimpringan. Rudat adalah sejenis kesenian tradisional yang semula tumbuh dan berkembang di lingkungan pesantren. Seni Rudat merupakan paduan seni gerak dan vokal dengan diiringi tabuhan ritmis dari waditra/alat musik rebana/ketimpring. Syair-syair yang terkandung dalam lagu-lagunya bernafaskan keagamaan, puji-pujian mengagungkan asma Alloh, Shalawat pada Rasul dengan tujuan utama untuk lebih menebalkan keimanan masyarakat terhadap agama Islam dan Keagungan Alloh.

Kesenian Ubrug, di Kabupaten Lebak dikenal juga dengan nama seni topeng. Dalam kamus bahasa Sunda, istilah "Ubrug" mengandung arti sebagai bangunan darurat tempat bekerja sementara untuk beberapa hari saja, misalnya untuk kepentingan hajatan atau pesta. Mungkin saja di masa lalu pemain ubrug suka berpindah-pindah tempat dan membuat bangunan sementara ketika mereka mengadakan suatu pertunjukan. Orang kemudian menyebutnya sebagai pemain ubrug, yakni pemain yang tinggal di tempat darurat. Ubrug adalah teater rakyat khas daerah Banten yang mengandung unsur lakon atau cerita dan didukung oleh unsur-unsur karawitan (musik), banyolan (lawakan, bodor), tari dan jajawaraan (pencak silat). Gaya bahasa yang dipergunakan menggunakan bahasa Sunda, Jawa maupun Indonesia dalam dialek Banten.

Kesenian Ubrug secara berangsur-angsur digunakan untuk hiburan pada acara hajatan, yakni selamatan pernikahan, khitanan, peresmian gedung perkantoran dan lain sebagainya. Di masa lalu seni ubrug diadakan sebagai hiburan melepas lelah dari beban berat bekerja di sawah-sawah dan diladang-ladang. Oleh karena itu, di masa lalu, seni ubrug diadakan di sawah-sawah dan diladang-ladang perkebunan setelah musim panen tiba. Dengan 
demikian, fungsi kesenian ubrug adalah sebagai hiburan terutama untuk menghilangkan kepenatan.

Kesenian Wayang Golek merupakan bentuk Teater Rakyat yang sangat popular, di dalamnya terdapat plot, tokoh, dialog, setting, dan tema cerita. Kelebihan lainnya pada Wayang Golek terdapat perpaduan yang lebih kompleks, di dalamnya terdapat seni rupa, karawitan sekar, karawitan gending, dan seni tari. Dalam pertunjukannya Wayang Golek membawakan lakon atau cerita dari babad Lokapala, Ramayana, dan Mahabarata.

Orang sering menghubungkan kata "wayang" dengan "bayang" karena dilihat dari pertunjukan Wayang Kulit yang memakai layar, di mana muncul bayang-bayangan. Wayang Kulit di Jawa Barat ada yang menggunakan boneka (dari kulit/ Wayang Kulit atau kayu/Wayang Golek) dan ada yang dimainkan oleh manusia (Wayang Orang). Ada dua macam Wayang Golek, yaitu Wayang Golek Papak (Cepak) dan Wayang Golek Purwa yang ada di daerah Sunda. Semua Wayang kecuali Wayang Orang, dimainkan oleh dalang sebagai pemimpin pertunjukan yang sekaligus menyanyikan suluk, menyuarakan antawacana, mengatur gamelan, mengatur lagu, dan lain-lain) (Atmadibrata, 2006: 163).

Alat musik yang digunakan adalah seperangkat gamelan berlaras salendro, terdiri atas dua buah saron, bonong indung, bonong rincik, peking, panerus, kenong, jenglong, gambang, kempul, gong, dan seperangkat kendang.

Keberadaan kesenian Wayang Golek di Kabupaten Lebak saat ini sangat memprihatinkan, hal tersebut disebabkan beberapa faktor, di antaranya: tidak adanya regenerasi dari dalang sepuh kepada generasi muda, minat masyarakat untuk mementaskan seni wayang golek berkurang, sarana prasarana yang tidak memadai, dan sebagainya. Dari kondisi tersebut tercatat, tinggal beberapa nama dalang yang ada di Kabupaten Lebak antara lain: Dalang Mijan di Kecamatan Cibadak, Dalang Tirta di Kecamatan Cikulur, Dalang Tata Wijaya di Kecamatan Leuwidamar, Dalang Supriatna di Kecamatan Sobang, Dalang Jajang Gumelar di Kecamatan Cibeber, Dalang Supriadi di Kecamatan Cihara, dan Dalang Baehaqi di Kecamatan Cibadak.

\section{Di Bidang Pendidikan}

Pada awal abad ke-20, sifat pendidikan berubah. Hal ini disebabkan adanya Politik Etis. Politik Etis merupakan garis politik kolonial baru yang pertama-tama diucapkan secara 
resmi oleh Van Deventer sebagai anggota Parlemen Belanda dalam pidatonya pada tahun 1891 dikemukakan keharusan untuk memisahkan keuangan Indonesia dari negri Belanda. Diperjuangkan pula kemajuan dan kesejahteraan rakyat serta ekspansi yang pada umumnya menuju kesuatuan politik yang konstrutif (Ekadjati at.al., 1986: 54).

Adanya Politik Etis telah mengubah pandangan dalam politik kolonial sehingga Pemerintah Belanda beranggapan bahwa Indonesia tidak lagi sebagai wingewest (daerah yang menguntungkan), tetapi menjadi daerah yang perlu dikembangkan supaya dapat memenuhi keperluan yang perlu dikembangkan sehingga dapat memenuhi keperluannya, dan budaya rakyatnya ditingkatkan (Kartodirdjo, 1977: 38 ).

Namun pendidikan yang sedang dijalankan oleh Pemerintah Belanda belum maksimal karena militerisme Jepang telah masuk ke wilayah Indonesia dan berhasil menaklukkan Pemerintah Belanda tepatnya pada tanggal 18 Maret 1942. Dengan menyerahnya Pemerintah Belanda, maka berakhir pula penjajahan di Indonesia dan memasuki periode baru, yaitu periode pemerintahan pendudukan militer Jepang. Segala peraturan atau aktivitas yang telah dijalankan pada zaman Belanda berhenti total. Termasuk program Politik Etis yang baru dijalankan oleh Pemerintah Belanda.

Setelah pendudukan militer Jepang mulai berkuasa, tidak ada satu pun sekolah menengah yang diperkenankan dibuka kembali atau segala kegiatan di sekolah harus berhenti termasuk di Lebak. Karena program-program untuk pendidikan belum dipersiapkan. Lagi pula tenaga pengajar atau guru-guru untuk mengajar di sekolah-sekolah mulai dari tingkat SD, SLTP, apalagi tingkat SLTA, sangat kurang karena ketika zaman Belanda tenaga pengajarnya kebanyakan dari orang Belanda sendiri dan dari pihak pribumi sendiri sedikit sekali.

Selain itu, Jepang masih berkonsentrasi ke masalah keamanan, menjaga bila terjadi hal-hal yang tidak diinginkan. Baru setelah merasa aman, sekitar bulan April 1942 Jepang menghimbau kepada seluruh rakyat Indonesia agar sekolah-sekolah yang pernah berdiri di zaman Belanda harap dibuka kembali. Di Kabupaten Lebak sekolah-sekolah yang sebelumnya telah ditutup, dibuka kembali seperti semula. Murid-muridnya pun masuk kembali ke tempat sekolahnya masing-masing.

Sistem pendidikan antara Pemerintah Belanda dengan pemerintah pendudukan militer Jepang sangat berbeda. Pemerintah Belanda sistem pendidikannya ditentukan sesuai dengan 
status sosial artinya yang bisa masuk sekolah adalah golongan bangsawan atau golongan ningrat, sedangkan rakyat biasa tidak boleh masuk sekolah. Pendudukan Jepang tidak melihat golongan atau status sosial, rakyat pun bisa masuk sekolah. Dalam pelajarannya, selain menggunakan bahasa Jepang, bahasa Indonesia pun mulai digunakan.

Setelah Proklamasi Kemerdekaan Republik Indonesia, tidak hanya diikuti oleh perubahan-perubahan dalam pemerintahan dan di bidang lainnya, tetapi juga bidang pendidikan. Perubahan di bidang pendidikan yang mendasar adalah perubahan dalam bidang landasan ideal, tujuan pendidikan, sistem persekolahan, dan kesempatan belajar. Berbeda dengan masa kolonial, landasan pendidikan pada masa kemerdekaan secara tegas dirumuskan, yaitu bahwa Pancasila merupakan landasan pendidikan nasional. Pendidikan pada tahun 1945-1950, ditujukan untuk mendidik warga negara yang sejati, bersedia menyumbangkan tenaga dan pikirannya untuk negara dan masyarakat. Pada tahun 1950 tujuan pendidikan ini kemudian disempurnakan antara lain, yaitu untuk mendidik manusia yang susila, cakap dan warga negara yang demokratis serta bertanggung jawab terhadap kesejahteraan masyarakat dan tanah air (Suryo, 1996:12).

Di Kabupaten Lebak pada akhir revolusi kemerdekaan, dari dua tingkatan sekolah menengah (SMTP dan SMTA) hanya terdapat SMTP, sedangkan SMTA tidak ada. Ada tiga sekolah menengah yang sederajat, yaitu: SMTP umum (Sekolah Menengah Pertama), SMTP kejuruan (Sekolah Menengah Ekonomi Pertama), dan SMTP keguruan (Sekolah Guru B). Di Kabupaten Lebak pada mulanya hanya terdapat satu Sekolah Menengah Pertama yang didirikan pada tahun 1948 oleh pihak swasta. Nama sekolah tersebut yakni SMP Nasional yang kemudian hari berubah menjadi SMP Negeri 1 Rangkasbitung (Lubis at al., 2006: 314).

Kemudian seiring kondisi politik, sosial, dan ekonomi di Kabupaten Lebak tahun demi tahun makin stabil dan membawa dampak yang sangat positip terhadap perkembangan pendidikan. Akhirnya pendidikan pun sedikit demi sedikit berkembang, baik secara kuantitas maupun kualitas. Sekolah-sekolah formal baik negeri maupun swasta dari berbagai tingkatan semakin banyak didirikan di seluruh kecamatan (Lubis at.al., 2006: 315-318).

Adapun sekolah yang didirikan dari tahun 1991 sampai dengan tahun 2004 menurut jenjang pendidikan di Kabupaten Lebak yaitu, sebagai berikut: 


\section{TABEL 3}

\section{JUMLAH SEKOLAH MENURUT JENJANG PENDIDIKAN DI KABUPATEN LEBAK TAHUN 1991-2004}

\begin{tabular}{|l|l|l|l|l|}
\hline No. & Tahun & \multicolumn{1}{|c|}{ S D } & S M P & S M A \\
\hline 1 & 1991 & 786 & 45 & 18 \\
\hline 2 & 1994 & 789 & 43 & 18 \\
\hline 3 & 1999 & 797 & 53 & 19 \\
\hline 4 & 2004 & 764 & 72 & 41 \\
\hline
\end{tabular}

Sumber : BPS Kabupaten Lebak, Lebak Dalam Angka 2005.

Tahun 1991 SD 786, SMP 45; tahun 1994 SD 789, SMP 43, SMA 18; tahun 1999 SD 797, SMP 53, SMA 19; dan tahun 2004 SD 764, SMP 72, SMA 41. ( BPS Dalam Angka, 2005).

Melihat keterangan di atas, perkembangan pendidikan di Kabupaten Lebak cukup signitifikan hal ini menunjukkan bahwa masyarakatnya makin sadar terhadap pendidikan. Pendidikan dapat mengantarkan pada kehidupan yang lebih baik, pendidikan pula yang akan mengubah watak dan kemampuan dari keadaan yang tidak baik menjadi baik, dan dari keadaan tidak mampu menjadi mampu. Apalagi dalam Pembukaan UUD 45 ditegaskan bahwa salah satu misi Pemerintah Republik Indonesia ialah "untuk mencerdaskan kehidupan bangsa". Kemudian ditegaskan lagi dalam pasal 31 ayat 1 UUD 45 bahwa setiap warga negara berhak mendapat pendidikan.

\section{PENUTUP}

Dari paparan di atas Kabupaten Lebak dahulunya disebut Jagat Kidul atau Banten Kidul (Banten Selatan), bagian wilayah Kesultanan Banten. Dalam pemerintahannya mengalami beberapa kali perubahan. Pertama, Kabupaten Lebak mempunyai empat distrik, yaitu: Lebak Parahyang, Cilangkahan, Sajira, dan Parungkujang. Kedua, ketika Hindia Belanda dipimpin oleh Gubernur Jenderal Frederik's Jacob (1881-1884), Kabupaten Lebak dibagi menjadi lima distrik, yaitu: Lebak Parahyang, Cilangkahan, Sajira, Parungkujang, dan Rangkasbitung. Ketiga, Pada tahun 1925 Lebak menjadi sebuah kabupaten otonom yang 
memiliki empat distrik yaitu Distrik Parungkujang, Rangkasbitung, Lebak Parahiyang, dan Cilangkahan. Sajira yang tadinya adalah sebuah distrik masuk menjadi bagian dari Distrik Lebak Parahiyang. Keempat, Pada Tahun 1950 Kabupaten Lebak dimasukkan ke dalam 25 Daerah Tingkat II di Provinsi Jawa Barat. Kelima, Kabupaten Lebak menjadi bagian dari Provinsi Banten.

Pertumbuhan penduduk Kabupaten Lebak mengalami turun naik dalam arti pada tahun 1834-1840 mengalami penurunan dan pada tahun 1850-1877 mengalami kenaikan. Mulai dari tahun 1920-1930 dan dari tahun 1961 sampai dengan tahun 1990 jumlah penduduk Kabupaten Lebak terus merangkak naik. Kebudayaan Lebak yang berkembang didominasi oleh kebudayaan Sunda. Begitu pula halnya dengan kesenian sebagai salah satu wujud kebudayaan juga didominasi oleh kesenian Sunda. Kesenian tradisional dan upacara tradisional peninggalan dari nenek moyang yang sampai sekarang masih eksis terutama di daerah Kanekes, seperti: Kesenian Angklung, dog dog Lojor, Debus, Rudat, Ubrug, Wayang Golek, dan sebagainya. Berdasarkan status sosial, masyarakat Lebak mengenal beberapa pelapisan sosial dalam kehidupannya, yaitu: Pertama, gelar tubagus (untuk laki-laki) dan ratu (untuk perempuan), gelar ini mempunyai hubungan darah dengan Kesultanan Banten. Kedua, gelar raden, ini mempunyai hubungan darah dengan menak Priangan, dan ketiga gelar entol.

\section{DAFTAR SUMBER}

Adeng at.al., 2007.

Kota Dagang Banten sebagai Bandar Jalur Sutra, Departemen Kebudayaan dan Pariwisata, Balai Pelestarian Sejarah dan Nilai Tradisional, Bandung.

at al., 2011

Peninggalan Sejarah di Kabupaten Lebak, Kementerian Kebudayaan dan Pariwisata, Balai Pelestarian Sejarah dan Nilai Tradisional, Bandung.

Atmadibrata, Enoch, 2006.

Khazanah Seni Pertunjukan Jawa Barat, Disbudpar Jawa Barat, Bandung.

Badan Pusat Statistik Kabupaten Lebak, 2005.

Kabupaten Lebak Dalam Angka 2005. Lebak. 
Bappeda, 2007.

Peta Administrasi Kabupaten Lebak dan Bakosurtana, Lebak.

Ekadjati, Edi S., 1986.

Sejarah Pendidikan Daerah Jawa Barat Sampai dengan Tahun 1950, Departeman Pendidikan dan Kebudayaan, Proyek Inventarisasi dan Dokumentasi Kebudayaan Daerah, Jakarta, 1986.

--------------------, 1995

Kebudayaan Sunda (Suatu Pendekatan Sejarah). Jakarta: Pustaka Jaya.

Ensiklopedia Nasional, Jilid 9, 1990.

Koentjaraningrat, 1984.

Kebudayaan Jawa, Jakarta: Balai Pustaka.

Kartodirjo, Sartono, 1977.

Sejarah Nasional, Jilid VI, Jakarta: Balai Pustaka

Lubis, Nina Herlina at.al., 2006.

Sejarah Kabupaten Lebak, Pemerintah Daerah kabupaten Lebak bekerja sama dengan Pusat Penelitian Kemasyarakatan dan Kebudayaan Lembaga Penelitian, Universitas Padjadjaran, Bandung.

Makmur, Ade, 2001

Pamarentahan Baduy di Desa Kanekes: Perspektif kekerabatan,.

Putra, H.S., Ahimsa, 2004.

Jejak Masa Lalu, Sejuta Warisan Budaya, Yogyakarta: Kunci Ilmu.

Rostiyati, Ani, 2011.

Sistem Gotong Royong di Lampung Timur (Kasus di Desa Negara Nabung, Kecamatan Sukadana, Kebupaten Lampung Timur), Dirjen NBSF, Direktorat Kepercayaan, Jakarta.

Suryo, Djoko, 1996. 
Pendidikan, Diferensiasi Kerja dan Pluralisme Sosial, Dinamika Sosial Ekonomi (1900-1990), Makalah disampaikan pada Kongres Sejarah Nasional Indonsia, Jakarta.

Sutisna, Agus at.al., 2004.

Lebak Dalam Arus. Perubahan: Kado Ulang Tahun Ke-176 Kabupaten Lebak, Lebak: Dinas Inkosbudpar Kabupaten Labak.

Sucipto, Toto at al., 2000.

Kebudayaan Masyarakat Sunda di Kabupaten Lebak Jawa Barat, Departemen Pendidikan dan Kebudayaan, Direktorat Jarahnitra, Proyek Pengkajian dan Pembinaan Nilai-nilai Budaya Jawa Barat, Bandung.

Sariyun, Yugo at al., 1991/1992.

Nilai Budaya dalam Permainan Rakyat Jawa Barat, Departemen Pendidikan dan Kebudayaan, Direktorat Jarahnitra, Proyek IPNB, Bandung.

Suyitno, Anan at al., 1991.

Bunga Rampai Jawa Barat, Bandung: Yayasan Wahana Citra Nusantara. 